\title{
MALAYSIAN HALAL CERTIFICATION: IT'S RELIGIOUS SIGNIFICANCE AND ECONOMIC VALUE
}

\author{
Rokshana Shirin Asa ${ }^{1}$
}

\begin{abstract}
Muslims consciously employ Shariah requirements in every aspect of their lives. It is their religious obligation to segregate between halal and haram. In the contemporary period, halal food is the most discussed matter around the world and the demand for it is on the rise. Taking this demand into consideration, the halal industry has become an important topic in Malaysia. The nation has standards and certification for halal, but the effectiveness of this system is dependent on a comprehensive and sound organizational structure. This study will examine how important the halal certification is in ensuring that the demand for halal food in Malaysia is met as well as the improvement of the halal industry and the extent halal certified food guarantee the rights of Malaysian Muslim consumers in compliance with Shariah principles. Presently, an issue relating to halal certification has become an important part of the industry. Malaysia is one of the pivotal and uprising stakeholders in the world's halal market. For this reason, a comprehensive halal awareness programme is needed to point out the importance of halal certification, this will
\end{abstract}

\footnotetext{
$1 \quad$ Lecturer, Department of Law, Prime University, Dhaka 1216, Bangladesh, asha
} law@hotmail.com 
not only enhance the Malaysian halal industry, but also enrich the Malaysian economy.

Keywords: Malaysia halal certification, halal industry, Muslim consumers' rights, importance of halal certification, Shariah compliance

\section{INTRODUCTION}

Malaysia has entered an era of halal development. The number of Muslims is increasing ${ }^{2}$ as are demands for halal products. ${ }^{3}$ Muslim as well as non-Muslim states ${ }^{4}$ are becoming more aware about halal consumption. Being Muslims, it is obligation to consume halal food, not as an obligation, but also as a means to show obedience to Allah (SWT). All over the world the halal industry is growing, effectively contributing to the global economy as well as social development. Malaysia is the first Muslim country where the government is acting progressively for the development of its halal industry for it has a high potential sector which positively contributes to the economy.

To uphold a trustworthy position in the world market, Malaysian halal certification plays an important role. Malaysia entered the global halal food market by opening international restaurants in the 1970 s. $^{5}$ From the beginning, Muslim consumers had expressed their eagerness about imported halal food products. They demanded that all imported food should be complying with Shariah guidelines. ${ }^{6}$ This driving force encouraged the Malaysian authority to promulgate standards as well as specific laws and regulations on this matter. This paved the way for Malaysia to provide halal food at the national and international level, highly recognized in the global market. The first legislative initiative in this respect was taken through the Trade Description Order 1975,

2 Adam Kredo, 'Muslim Population Increasing Faster than Entire World Population,' The Washington Free Beacon, http://freebeacon.com/issues/muslim-populationincreasing-faster-than-entire-world-population, accessed 20 December 2015.

3 Alqudsi, Syed Ghazaly, 'Awareness and Demand for 100\% Halal Supply Chain Meat Products,' Procedia-Social and Behavioral Sciences, 130 (2014): 167-178.

4 E. Rios, Rosa, Hernan E. Riquelme \& Yasser Abdelaziz, 'Do Halal Certification Country of Origin and Brand Name Familiarity Matter?' Asia Pacific Journal of Marketing and Logistics, 26/5 (2014): 665-686.

5 Fischer, Johan, 'Malaysian Diaspora Strategies in a Globalized Muslim Market,' Geoforum, 59 (2015): 169-177.

6 Bergeaud-Blackler, Florence, Johan Fischer \& John Lever, Halal Matters: Islam, Politics and Markets in Global Perspective (London \& New York: Routledge, 2015), 1-18. 
which mandated that the use of false halal labels on food products would be a punishable offence. ${ }^{7}$

Another initiative was made in 1982 when the Prime Minister's Department under the Islamic Affairs Division established a committee on the assessment of food, drinks, and goods consumed by Muslims. ${ }^{8}$ This committee is responsible for inspecting and introducing awareness among halal food manufacturers, suppliers, and traders. In addition, in the same year the Malaysian government made a regulation that all meat (beef, mutton, veal, and poultry) imported into Malaysia must have halal certification - and such meat should only come from abbattoirs approved by the Islamic Affairs Division of the Prime Minister's Department and the Department of Veterinary Services. Afterwards, a new agency was formed called Jabatan Kemajuan Islam Malaysia (JAKIM), or Islamic Development Department of Malaysia. JAKIM together with us started to play important roles in the management of halal certification on behalf of the Malaysian government. ${ }^{9}$

JAKIM is the core controlling body that administers Malaysian halal certification for food products and it creates policies which are decided by the cabinet. JAKIM issues the halal certification logo and approves products which strictly fulfill the halal requirements in accordance to the Shariah laws. These policies and standards are operated by JAKIM and JAIN for the purpose of halal certification. Apart from JAKIM, the State Islamic Religious Departments (JAIN) or State Islamic Religious Councils (Majlis Agama Islam Negeri hereafter termed as MAIN) are also accepted bodies for certification. In addition, there are 73 foreign certification bodies that have been recognized by JAKIM as of April 14th 2017. ${ }^{10}$

7 Zakaria, Zalina, 'Tapping into the World Halal Market: Some Discussions on Malaysian Laws and Standards,' Shariah Journal, 16/3 (2008): 603-616.

8 Hisyam, M., 'The Prospect of Halal Concept for Muslim Manufacturers,' http:// www.ikim.gov.my/index.php/en/artikel/7313-the-prospect-of-halal-concept-formuslim-manufacturers, accessed 14 March 2013.

9 Ismail, Zahari \& Abdul Halim Ehsan, 'Halal Nutraceutical Market: Issues and Challenges,' in Proceedings of the Asian Forum on Business Education 2008 on Contemporary Issues in doing Business in Asia, 3-4 December (Kuala Lumpur: University of Malaya, 2008); Abdullah, Tengku Akbar Tengku \& John Jackson Ireland, 'Halal Products: The Views of Muslim Consumers Across Malaysia,' Journal for International Business and Entrepreneurship Development, 6/3-4 (2012): 260-273.

10 Halal Malaysia, 'The Recognized Foreign Halal Certification Bodies and Authorities,' Halal Hub Division, Department of Islamic Development Malaysia (JAKIM), http://www.halal.gov.my/v4/index.php/en/badan-islam, accessed 31 July 2017. 
However, the government has reorganized the issuance of halal certificates whereby JAKIM certifies the food product procedure in Malaysia and for export and JAIN issues certificates for specific states only with the same halal logos. For the purpose of synchronization and coordination, JAKIM is working closely with SIRIM (Standards and Industrial Research Institute of Malaysia) and DSM (Department of Standards Malaysia) together for the development of a Malaysian halal food standard. In this respect, the Malaysian halal certificate is issued by the government only. On the other hand, Islamic organizations are authorized to certify halal products in other countries. In addition, JAKIM has developed its own halal manual procedure for the purpose of applying, auditing, and monitoring halal certification.

Another purpose of JAKIM is to work as an implementation authority that imposes lawful provisions, operational principles, and strategies for halal business to comply with. After the amendments of the Trade Description Act 2011, JAKIM has been authorized to carry out enforcement activities against any business holder or individual who misuses the halal logo. Also, many by-laws were amended, including the Trade Description (Use of Expression Halal) Order 1975, the Trade Description (Halal Labeling) Order 1975, the Trade Description (Definition of Halal) Order 2011, the Trade Description (Certification and Marking of Halal) Order 2011, and the Trade Description (Certification and Marking of Halal Fees) Regulations 2011. The objectives of these amendments to the TDA 2011 were to insert some provisions towards reforming the loopholes in the laws regarding trade and halal. There were numerous sections added, such as, Sections 9 (1 and 2), 16, 20, 23, 32 and in the case of halal regulations, the most important introductions were Sections 28 and 29.

The new amended Act 2011, like its predecessor, promotes good trade practices and prohibits false trade; as well as statements and conduct in relation to goods and services. The most noteworthy feature of this amendment was the introduction of the Trade Description (Definition of Halal) Order 2011, the Trade Description (Certification and Marking of Halal) Order 2011, and the Trade Description (Halal Certification and Marking Fees) Order 2011 which provide specific legal provisions on matters related to halal. These three bylaws were enforced on $1^{\text {st }}$ January 2012. 


\section{LITERATURE REVIEW}

\section{Impression of Islam}

Islam is a religion which offers an approach of beliefs and practices that assists an individual's response and interpretation regarding the supernatural and the sacred. ${ }^{11}$ It is the main cultural component in the Muslim world which influences consumers to determine their foods selection, ${ }^{12}$ behaviour, consumption habits, and purchasing decisions. ${ }^{13}$ In Islam, supremacy goes to Allah. Therefore, everything has to be done for the sake of Allah only. As such, Muslims are bound to follow the principles of Shariah and consume halal products.

\section{Halal in Shariah}

The expression 'halāl' means that which is permissible and lawful; its opposite is 'harām', ${ }^{14}$ which is an act or object forbidden in the sight of Allah SWT. To this end, Allah SWT commands Muslims and all of mankind to eat only halal things. In the Qur'ān, Allah SWT states that:

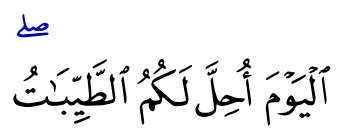

"This day all things good and pure have been made lawful to you..."

(Surah al-Mā'idah, 5: 5)

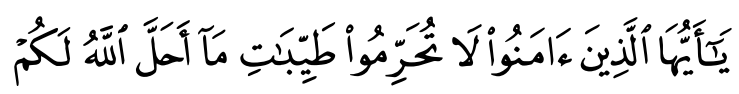

"Ye who believe! Forbid not the good things that Allah SWT has made halal for you..."

(al-Mā’idah, 5: 87)

11 Johnstone, Ronald L., Religion and Society in Interaction: The Sociology of Religion (New Jersey: Prentice Hall, 1975), 345.

12 Dindyal, Shiva \& Sanjay Dindyal, 'How Personal Factors, Including Culture and Ethnicity, Affect the Choices and Selection of Food We Make,' Internet Journal of Third World Medicine, 1/2 (2003): 27-33.

13 Shatenstein, Bryna \& Parviz Ghadirian, 'Influences on Diet, Health Behaviours and their Outcome in Select Ethnocultural and Religious Groups,' Nutrition, 14/2 (1998): 223-230.

14 Qaradawi, Y. Al., The Lawful and the Prohibited in Islam, 2nd ed. (Cairo, Egypt: Al Falah Foundation for Translation, Publication \& Distribution, 2001), 14-36. 
Elsewhere, Allah SWT states another principle regarding halal and haram:

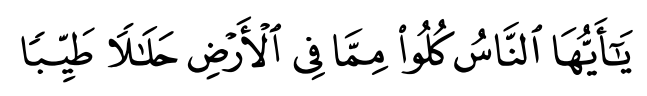

"O, mankind! Eat of that which is lawful and wholesome in the earth..."

(Surah al-Baqarah, 2: 168)

The verses indicate that food not only have to be halal, but also (tayyib) pure. As such, one of the main objectives of Islamic law is to protect human beings from consuming any food or drink which may cause harm to their bodies and health. Thus Allah SWT says:

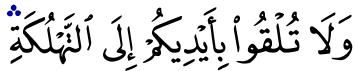

"And make not your own hands contribute to (your) destruction..."

(Surah al-Baqarah, 2: 195)

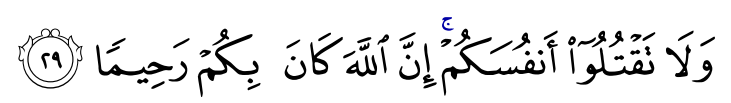

"Nor kill (or destroy) yourselves for verily Allah has been to you the Most Merciful..."

(Surah al-Nisā', 4: 29)

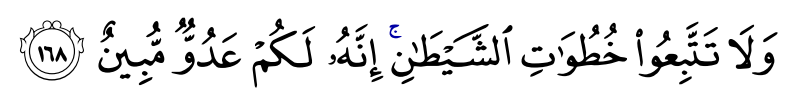

"Follow not the footsteps of the devil. Lo! He is an avowed enemy of you..."

(Surah al-Baqarah, 2: 168).

Along with these statements, Islam provides clear guidelines on food processing in relation to the fulfillment of halal requirements. Allah SWT says:

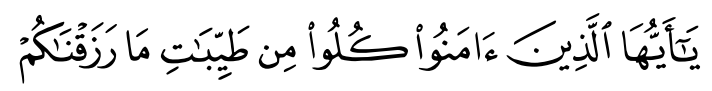

"O ye who believe! Eat of the good things that we have provided for you..."

(Surah al-Baqarah, 2: 172)

In addition to the abovementioned Qur'anic verses, some hadith from the Holy Prophet Muhammad (PBUH) also address the sources of halal food, products, and drinks for human consumption. The hadith related to this 
circumstance was narrated on the authority of Abū Ya'la Shaddad Ibn 'Aws, who said that the Messenger of Allah (PBUH) said:

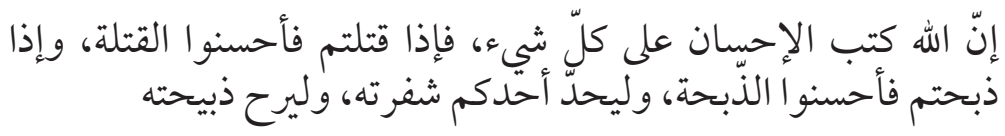

"Verily Allah has prescribed proficiency in all things. Thus, if you kill, kill well; and if you slaughter, slaughter well. Let each one of you sharpen his blade and let him spare suffering to the animal he slaughters..." 15

This indicates that Islam provides perfect guidelines on the halal food process. In another instance, it was narrated by Rafi' bin Khadij that the Prophet (PBUH) told Muslims who wanted to slaughter some animals using reeds the following:

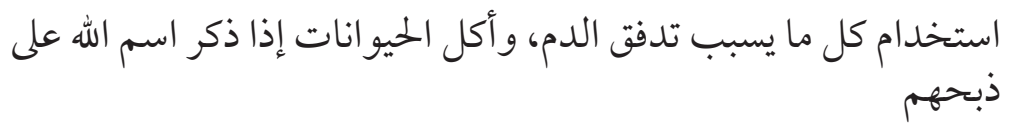

"Use whatever causes blood to flow, and eat the animals if the name of Allah has been mentioned on slaughtering them..." 16

According to the above narration, it evidently mentions that Islam is very concerned about matter of food processing in relation to the fulfillment of halal requirements. As Muslims we have to follow the Shariah principles in every sphere of life. Allah SWT says in this regard:

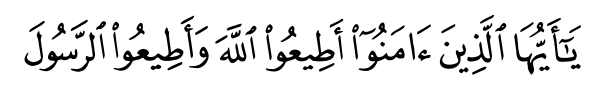

"O you who believe! Obey Allah and obey the Messenger..."

(Surah al-Nisā', 4: 59)

\section{Significance of Halal Consumption}

The importance of halal consumption has two aspects: religious and scientific. Muslims consume halal food because of the accountability and belief that it is

15 Abū al-Ḥusayn Muslim Ibn al-Hajjāj al-Nīsābūrī, Șaḥ̄ḥ Muslim, vol. 6/11 (Beirūt: Dār al-Kutub al-'Ilmiyyah, 2003), "Kitāb al-Musāqāt: Bāb Bay' al-Ba'īr wa Istithnā' rukubihi," no. hadìth 17.

16 al-Bukhārī, Șaḥīh al-Bukhārī, vol. 3 (Beirūt: Dār al-Kutub al-'Ilmiyyah, 2003), 44, "Kitāb al-Syurūṭ: Bāb idhā Ishtarața al-Bā’i'u Dhahr al-Dābbah," no. hadìth 668 . 
appropriate for consumption. ${ }^{17}$ Halal status is generated from the instructions set out in the Qur'ān and hadith. Therefore, halal is considered a religious obligation. For Muslims, halal is what is approved both in dietary intake and in actions. In addition, Allah SWT says:

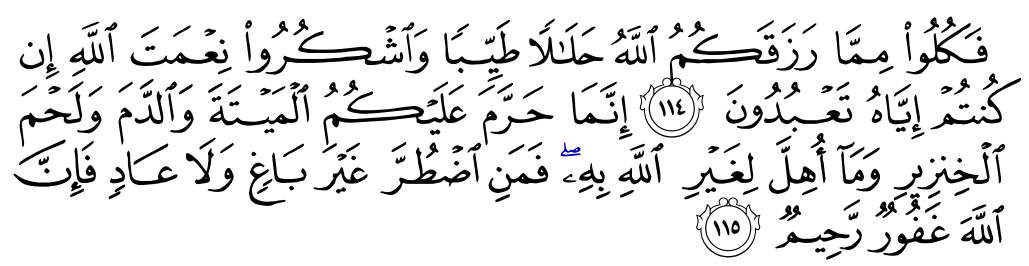

"So eat of the sustenance which Allah has provided for you, lawful and good; and be grateful for the favors of Allah, if it is He whom ye serve. He has only forbidden you dead meat, blood, flesh of swine, and any foods over which the name of other than Allah has been invoked. But if one is forced by necessity, without willful disobedience, not transgressing due limits, then Allah is oft forgiving and most merciful..."

(Surah al-Nahıl, 16: 114-115)

By showing this gratitude, Muslims can protect their religion (hifz al-din), protect themselves (hifzal-nafs), protect the mind (hifz al- 'aql), protect wealth and property (hifz al-māl), and protect their progeny (hifz al-nasl). Hence, halal consumption has significant effects on our lives. Being a Muslim, in every part of our life, halal is mandatory. And for survival, food is essential for every human being. Therefore, Muslims have Islamic dietary rules. According to these rules, only halal foods are permitted for consumption. For that reason, by following the Islamic dietary code means the Muslim is worshipping Allah SWT and this will lead to Allah's blessings to Muslims lives.

Moreover, halal food contains nutrition and is hygienic, which is also proven by scientific research. ${ }^{18}$ Clean and hygienic food guarantees a healthy body.

17 Mustafar, Mohd Zaid \& Joni Tamkin Borhan, 'Muslim Consumer Behavior: Emphasis on Ethics from Islamic Perspective,' Middle-East Journal of Scientific Research, 18/9 (2013): 1301-1307.

18 Alice Park, 'Is Halal Meat Healthier than Conventional Meat?' http://time. com/3975785/is-halal-meat-healthier-than-conventional-meat., accessed 12 December 2016. 
Therefore, along with choosing permitted foods, it is best to emphasize the aspect of cleanliness and hygiene in accordance to the instructions of Islam. ${ }^{19}$

\section{Connotation of Halal Certification Mark}

An ordinary trademark differs from a certification trademark because the latter provides a guarantee that those goods and services have accomplished specific requirements. Halal certification, as a symbol of value, health, and protection of animal rights, not only works as an assurance to verify the product's conformity to Islamic dietary laws, but also ensures that it comprises all the permitted elements. According to Phelps:

"Certification marks and quality labels as marks are used upon or in the products and services of one and more person to certify regional or other origin, material, mode of manufacture, quality, accuracy or other characteristics of such goods or services..." 20

Halal certification is needed to inform Muslim consumers that products are prepared by halal methods. Through the halal assurance system, haram products can be identified. Halal labeling legislation also protects the rights of consumers. Having a specific logo demarcates food products as permissible and impermissible. The purpose of this certification is to aid the buyer in purchasing the right products. The Malaysian halal certificate is recognized worldwide and all the credit goes to its halal industry. The progressive development of Malaysian halal industry has become a model for other countries. Many Muslim as well as non-Muslims countries are following Malaysian standards, along with its laws.

\section{METHODOLOGY}

This study has adopted the method of literature review, relying on both primary and secondary sources. The primary sources include statutes and judicial cases related to halal certification in Malaysia and other jurisdictions, while the secondary sources comprise of library materials (textbooks, journal articles,

19 Fadzlillah, Nurrulhidayah A., Yaakob Che Man, Mohammad Aizat Jamaludin, Suhaimi Ab Rahman \& Hassan A. Al-Kahtani, 'Halal Food Issues from Islamic and Modern Science Perspectives,' in International Conference on Humanities, Historical and Social Sciences, vol. 17 (Singapore: IACSIT Press, 2011), 159163.

20 Phelps, D. M., 'Certification Marks Under the Lanham Act,' The Journal of Marketing (1949): 498-505. 
and newspapers), internet resources (i.e. online databases) and annual reports of JAKIM and Ministry of Domestic Trade, Cooperatives and Consumerism (MDTCC).

\section{OVERVIEW OF GLOBAL HALAL MARKET AND MALAYSIAN HALAL INDUSTRY}

The consciousness of Muslim consumers regarding their religious obligations has created a demand for halal products. According to 2010 statistics, the Muslim population in the world was 1.8 billion; ${ }^{21}$ from 2010 to 2020 , it is estimated to increase to 1.9 billion, ${ }^{22}$ and from 2020 to 2030 the projected Muslim population may be 2.2 billion. ${ }^{23}$ In line with the rapid growth of the Muslim population, the Gross Domestic Product (GDP) per capita within Muslims-majority nations will also grow considerably at around $6.8 \%$ annually. ${ }^{24}$ For these reasons, the demands for halal products particularly food will also rise.

The global halal markets were USD 2.3 trillion and it is predicted to reach USD 6.4 trillion by $2018 .{ }^{25}$ According to another study, the scenario of the global halal trade is growing and it is expected to jump nine-fold to $\$ 10$ trillion by $2030 .{ }^{26}$ Present statistics shows that Asia is the fastest growing and most lucrative halal market; its value is nearly USD 418 billion. ${ }^{27}$ Among the Asian countries, Malaysia's contribution is USD 1.9 billion. $^{28}$

21 Jaffar, Mariatul Aida \& Rosidah Musa, 'Determinants of Attitude towards Islamic Financing among Halal-Certified Micro and SMEs: A Preliminary Investigation,' Procedia-Social and Behavioral Sciences, 130 (2014): 135-144.

22 Grim, Brian J. \& Mehtab S. Karim, The Future of the Global Muslim Population: Projections for 2010-2030 (Washington DC: Pew Research Center, 2011), 39.

23 Grim, Brian J. \& Mehtab S. Karim, The Future of the Global Muslim Population: Projections for 2010-2030, 14.

24 Global Islamic Finance Report (GIFR), 'Briefing to Members of Parliament,' http://www.gifr.net, accessed 23 December 2015.

25 Global Islamic Finance Report (GIFR), 'The Global Halal Industry: An Overview,' http://gifr.net/gifr2013/ch_13.PDF, accessed 23 December 2015.

26 Staff Report, 'Halal market to hit \$10t by 2030: Study,' Khaleej Times, 19 February 2014.

27 Global Islamic Finance Report (GIFR), 'The Global Halal Industry: An Overview,' http://www.gifr.net, accessed 23 December 2015.

28 Global Islamic Finance Report (GIFR), 'The Global Halal Industry: An Overview,' http://www.gifr.net, accessed 23 December 2015. 
Taking into consideration the development of the global halal market, many countries have passed laws, such as Brunei, which has the Halal Meat Act; Halal Meat Rules, 2008; Halal Certificate and Halal Label Order, 2005; and the Guidelines for Halal Certification. Indonesia also has the Halal Product Guarantee Law (Act no. 33). Section 88(A) of AMLA (Administration of Muslim Act) of Singapore provides the details on halal certification related matters and established halal guidelines and awareness programmes, not only to regulate international markets for the purpose of export, but also to create new halal markets in their own territories.

The recent halal export value shows that Malaysia is aggressively promoting itself as a leader in the global industry. The export value has risen steadily from MYR 32.8 billion in 2013 to MYR 37.7 billion in 2014. ${ }^{29}$ In 2015, Malaysian halal exports amounted to more than MYR40 billion ${ }^{30}$ and 2016 halal export value is expected to hit MYR 50 billion. ${ }^{31}$ The major bulk of halal exports were food and beverages (MYR 15.48 billion), ingredients (MYR 12.16 billion), palm oil (MYR 5.3 billion), cosmetic and personal care (MYR 2.31 billion), industrial chemicals (MYR 1.92 billion), and pharmaceutical products (MYR 0.51 billion). ${ }^{32}$ In this growing market, producers and manufacturers are required to have their products stamped with a halal logo in order to distinguish their goods from other products. In Malaysia, there are 4,785 companies $^{33}$ which have been certified by Department of Islamic Development Malaysia (JAKIM) out of $1,113,465^{34}$ registered companies at the Companies Commission of Malaysia. Many companies are looking at the halal concept as a new trademark for marketing. This large market has caught

29 Global Islamic Finance Report (GIFR), 'The Global Halal Industry: An Overview,' http://www.gifr.net, accessed 23 December 2015.

30 Susanna Lim, 'Time to Expand Halal Exports Beyond the Current Horizon,' www. matrade.gov.my/.../2890-time-to-expand-halal-exports-beyond-the-current-hori., accessed 20 November 2016.

31 Global Islamic Finance Report (GIFR), 'Malaysia's Halal Exports Rise 30 pct y/y for first nine months of 2015,' http://www.salaamgateway.com/en/pharmacosmetics/story/malaysias halal exports rise 30 pct yy for first nine months of 2015 salaam17012016040828/, accessed 20 November 2016.

32 Global Islamic Finance Report (GIFR), 'The Global Halal Industry: An Overview,' http://www.gifr.net, accessed 23 December 2015.

33 Oxford Business Group, 'The Report: Malaysia 2012,' https://books.google.coml, accessed 15 December 2015.

34 Suruhanjaya Syarikat Malaysia, 'Number of Registered Companies and Businesses,' https://www.ssm.com, accessed 2 December 2015. 
the attention of the world over and it's increasing. Even some non-Muslim countries have their own rules in respect to halal food imports and exports.

\section{Importance of Halal Certification from the Religious and Economic Aspects}

In Malaysia, the halal industry is becoming a significant area that can effectively contribute to the national economy. Presently, the industry's contribution is less than $2 \%$ and is expected to increase to $5.8 \%$ in the country's gross domestic plan by $2020 .{ }^{35}$ The objective of this industry is to guarantee the cleanliness and purity of the food for Muslim consumers use and purchase.

In Malaysia, the country's Halal Master Plan has been approved by the Cabinet in May 2008.

It signifies the issues of certification, halal integrity, implementation, timeframes, and responsibilities. ${ }^{36}$ By considering these concerns, the government of Malaysia has undertaken important actions to support the development of halal certification. To achieve the goal of creating a halal hub, the Malaysian government must quickly become the center for the certification of halal products. Halal certification is now under the purview of the Department of Islamic Development Malaysia (JAKIM). In addition, JAKIM issues halal certificates to local and global markets and is also responsible for the monitoring and enforcing of halal certification.

Islam has comprehensive guidelines for Muslims. How a Muslim should spend the whole day from morning to night, each and every single act is specifically explained by the Qur 'ān and sunnah. For that reason, a Muslims' life should be within the jurisdiction of a halal lifestyle. Therefore, consuming halal food is a religious obligation. ${ }^{37}$ It is not an insignificant thing that can be ignored. Being Muslims, our main objective is to follow Allah's SWT guidelines in our public as well as our private lives.

In general, eating is considered a simple action, but as Muslims, consuming halal food is obligatory and is a form of worshipping Allah SWT. The 'Maqāșid

35 Global Islamic Finance Report (GIFR), 'The Global Halal Industry: An Overview,' http://www.gifr.net, accessed on 23 December 2015.

36 Antara, P. M., Musa, R. \& Hassan, F., 'Theorising Attitude Towards Islamic Financing Adoption in An Integrative Model of Behavioural Prediction: A Proposed Conceptual Framework,' Journal of Administrative and Business Studies, 1/1 (2015): 35-41.

37 Mukhtar, Arshia \& Muhammad Mohsin Butt, 'Intention to Choose Halal Products: The Role of Religiosity,' Journal of Islamic Marketing, 3/2 (2012): 108-120. 
Shari' 'ah' (objectives of Islam) are to preserve the purity of the religion, to safeguard the reason, to protect life, to look after wealth, to safeguard our future generations, and to maintain our self-respect and integrity. ${ }^{38}$ Beside on this, consuming halal food is the way by which a Muslim accomplishes the rewards of Allah SWT and shows his or her compliance to the rules of Shariah. Hence, every life will be protected and safeguarded in order to uphold human rights.

\section{FINDINGS AND DISCUSSION}

Throughout the world there are various Islamic agencies that issue halal certification. They provide the assurance to consumers that the food ingredients and processes involved in making them are Shariah compliant. Halal certification is a means to ensure customer satisfaction, assurance, and reliance. Furthermore, it requires not only the food served to be halal, but also the entire process involved in producing it. Halal certified food demands a high level of hygiene, certain standards of cleanliness, safety, and nutrition which fulfills the needs of consumers. But getting genuinely halal food and products for Muslim consumers is quite difficult because there are lots of products with unauthorized halal labels. The halal logo is often misused in the market because of the lack of security on its use; the logo is easily copied, reproduced, and sold by perpetrators. A genuine halal logo has significant impact on today's businesses. Some cases of fraud have been reported. For example, on the $5^{\text {th }}$ of February, 2014 the enforcement officer of the Domestic Trade, Cooperative and Consumerism Ministry raided a fish ball processing factory where they used a halal logo not recognized by the Islamic Development Department of Malaysia (JAKIM).

Another incident happened on the $3^{\text {rd }}$ of March, 2014 when officers from the Kelantan office of the Domestic Trade, Cooperatives and Consumer Ministry raided a factory and seized various types of detergent worth about RM 12,000 because they did not carry a valid halal logo and the halal logo licensed to the factory had long expired in January 2012. Apart from using an unauthorised halal logo, some perpetrators did not rightly separate haram foods from halal, as found in $19^{\text {th }}$ August 2013 where some hypermarkets in the Federal Capital do not have separate sections for halal and non-halal food. This could have

38 Riaz, M. N. \& Chaudry, M. M., 'The Value of Halal Food Production-Mian N. Riaz and Muhammad M. Chaudry define what Halal and kosher foods are, describe why they are not the same thing, and what is required of processors and,' International News on Fats Oils and Related Materials (INFORM), 15/11 (2004): 698-701. 
posed a serious problem to Muslim consumers as most of them didn't have the time to check the ingredient and actual halal status of these food products. ${ }^{39}$

Most of the markets are dominated by non-Muslims and they have begun to understand the significance of halal products as consumers have started demanding them. In theory, there are some guidelines and procedures in the process of halal certification in Malaysia, but in reality there is a gap in its implementation, and the above mentioned cases are evidence of this. As such, the following issues are of concern:

1. There are still many products in the market produced locally that use a halal logo not recognized by JAKIM. It is envisages that the enforcement divisions of MDTCC and JAKIM have filed 120 cases on abuse of halal logo. Out of these 120 cases 64 cases are almost settled and the rest 56 cases are pending in different jurisdictions from September 2011 to September 2015.40

2. Due to the fact that the logo and certificate are easily copied, reproduced, and sold by the perpetrators, consumers have been deceived into consuming non-halal products, thus raising questions about the validity of halal products.

3. The fraudulent use of the halal logo and certificate infringes on the rights of Muslim consumers, which also affects Malaysia's reputation as a global halal hub.

Furthermore, the lack of enforcement and the monitoring of activities have made its future vulnerable. For the expansion of halal food and products, we need effective monitoring around the world. A strong regulatory framework can ensure halal products are properly certified and can expand the halal market. Malaysia has projected a plan to be a halal hub by 2020. In responding to this vision, the government is trying to set Malaysia as an example for other countries in the distribution, production, and promotion of halal products and services. As mentioned earlier, according to the $9^{\text {th }}$ Malaysian plan, the country will promote halal certification globally and be the main center for the certification of halal food. In view of the growing market for halal products and to make it easier for buyers to get these products, well-certified producers need to be identified. The requirements for the import and export of products

39 Pnakj Rv Mo, 'Jakim Urged To Monitor Use of Halal Logo at Hypermarkets,'The Edge, 19 August, 2013, BLIS, via IIUM Library, http://www.lib.iium.edu.my/ index.jsp?module $=$ ROOT\&action $=$ onlinedb.jsp

40 Othman Nawang (Deputy Director of Enforcement Division, Ministry of Domestic Trade, Cooperatives and Consumerism), in interview with author, 5 October 2015. 
at the domestic and international levels are the same, but the methods and procedures of implementation are different from one country to another. Based on this fact, the Malaysian government has enacted laws and formulated procedures and guidelines for domestic and imported halal products. Today's issues relating to halal certification and verification have become a business in and of itself and as well as the enhancement of the halal industry.

\section{CONCLUSION}

In summary, it can be said that each religion has its own unique characteristics, and in the case of Islam, halal is one of these unique features. Islam is a comprehensive lifestyle for Muslims. Every aspect of a Muslims life is covered by Islamic guidelines and principles, which are provided by the Qur'an and the sunnah of the Prophet Muhammad (PBUH). Among these guidelines, there is clear a narration that Muslims should practice a halal lifestyle.

In Malaysia, halal certification is authoritative; it is a symbol of assurance and confidence. Halal certified products not only have economic implications, but social as well. Malaysian halal certification is broadly acknowledged, which can become an example to other nations. At the present time, halal certification is no longer within the jurisdiction of the state; it belongs to the international community as well. In response to this vision that Malaysia is to be a halal hub, the government is trying to set the nation as an example for other countries in the distribution, production, and promotion of halal products and services. Nevertheless, ineffective regulations and poor administration can create doubts. Effective monitoring should be adopted to increase confidence among Muslims and the stability in Malaysian halal certification. Such a program is necessary to enhance the halal industry. However, the existing monitoring structures are still in the development stage. Without collective efforts to improve this arrangement, it will be challenging to gain the confidence of Muslim consumers and promote stability and the future expansion of the Malaysian halal industry for the rest of the world. A steady structure and normative certifying processes can also enhance the country's recognition and reliability in the global halal network.

\section{ACKNOWLEDGEMENTS}

The authors would like to express their humble gratitude to the honourable Professor Dr. Ida Madieha Abd. Ghani Azmi and Asst. Professor Dr. Noriah Ramli, Faculty of Law, International Islamic University Malaysia, for their 
intellectual assistance in the completion of this paper. Recognition is also given to the International Institute for Halal Research and Training (INHART).

\section{REFERENCES}

Abdullah, Tengku Akbar Tengku \& John Jackson Ireland, 'Halal Products: The Views of Muslim Consumers Across Malaysia,' Journal for International Business and Entrepreneurship Development, 6/3-4 (2012): 260-273.

Abū al-Husayn Muslim Ibn al-Hajjāj al-Nīsābūrī, Ṣaḥịh Muslim, vol. 6/11 (Beirūt: Dār al-Kutub al-'Ilmiyyah, 2003), "Kitāb al-Musāqāt: Bāb Bay" al-Ba'īr wa Istithnā' rukubihi," no. hadìth 17.

Adam Kredo, 'Muslim Population Increasing Faster than Entire World Population,' The Washington Free Beacon, http://freebeacon.com/issues/ muslim-population-increasing-faster-than-entire-world-population, accessed 20 December 2015.

Alqudsi, Syed Ghazaly, 'Awareness and Demand for 100\% Halal Supply Chain Meat Products,' Procedia-Social and Behavioral Sciences, 130 (2014): 167-178.

Ahmad, Azlin Alisa, 'Enforcement of Consumer Protection Laws on Halal Products: Malaysian Experience,'Asian Social Science, 10/3 (2014): 9-14.

Alice Park, 'Is Halal Meat Healthier than Conventional Meat?' http://time. com/3975785/is-halal-meat-healthier-than-conventional-meat., accessed 12 December 2016.

Antara, P. M., Musa, R. \& Hassan, F., 'Theorising Attitude Towards Islamic Financing Adoption in An Integrative Model of Behavioural Prediction: A Proposed Conceptual Framework,' Journal of Administrative and Business Studies, 1/1 (2015): 35-41.

Audi T., 'Muslim Population Projected to Nearly Match Christian by 2050,' The Wall Street Journal, http://www.wsj.com, accessed on 2 April 2015.

Aziz, Norazlina Abdul \& Siti Sarah Sulaiman, 'Role of the Local Authority in Issuing License for Halal Certified Premise in the City of Shah Alam,' Procedia-Social and Behavioral Sciences, 121 (2014): 133-143.

Bergeaud-Blackler, Florence, Johan Fischer \& John Lever, Halal Matters: Islam, Politics and Markets in Global Perspective (London \& New York: Routledge, 2015). 
al-Bukhārī, Șahịh al-Bukhārī, vol. 3 (Beirūt: Dār al-Kutub al-'Ilmiyyah, 2003), 44, "Kitāb al-Syurūṭ: Bāb idhā Ishtarața al-Bā'i'u Dhahr al-Dābbah," no. hadith 668 .

Business in Malaysia, 'Malaysia: Open for Halal Business,' http://business. malaysia.my, accessed on 2 January 2016.

Dindyal, Shiva \& Sanjay Dindyal, 'How Personal Factors, Including Culture and Ethnicity, Affect the Choices and Selection of Food We Make,' Internet Journal of Third World Medicine, 1/2 (2003): 27-33.

E. Riquelme \& Yasser Abdelaziz, 'Do Halal Certification,' Third World Medicine, 1/2 (2003): 27-33.

E. Rios, Rosa, Hernan E. Riquelme \& Yasser Abdelaziz, 'Do Halal Certification Country of Origin and Brand Name Familiarity Matter?' Asia Pacific Journal of Marketing and Logistics, 26/5 (2014): 665-686.

Fischer, Johan, 'Malaysian Diaspora Strategies in A Globalized Muslim Market,' Geoforum, 59 (2015): 169-177.

Fadzlillah, Nurrulhidayah A., Yaakob Che Man, Mohammad Aizat Jamaludin, Suhaimi Ab Rahman \& Hassan A. Al-Kahtani, 'Halal Food Issues from Islamic and Modern Science Perspectives,' in International Conference on Humanities, Historical and Social Sciences, vol. 17 (Singapore: IACSIT Press, 2011), 159-163.

Global Islamic Finance Report, 'Briefing to Members of Parliament,' http:// gifr.net, accessed 23 December 2015.

Global Islamic Finance Report, 'The Global Halal Industry: An Overview,' http://gifr.net/gifr2013/ch_13.PDF, accessed 23 December 2015.

Global Islamic Finance Report, 'Malaysia's Halal Exports Rise 30 pct y/y for first nine months of 2015,' http://www.salaamgateway.com/en/ pharma-cosmetics/story/malaysias_halal_exports_rise_30_pct_yy for_first nine months_of_2015-salaam 17012016040828/, accessed 20 Nonember 2016.

Grim, Brian J. \& Mehtab S. Karim, The Future of the Global Muslim Population: Projections for 2010-2030 (Washington DC: Pew Research Center, 2011).

Halal Malaysia, 'The Recognized Foreign Halal Certification Bodies and Authorities,' Halal Hub Division, Department of Islamic Development Malaysia (JAKIM), http://www.halal.gov.my/v4/index.php/en/badanislam, accessed 31 July 2015. 
Hisyam, M., 'The Prospect of Halal Concept for Muslim Manufacturers,' http://www.ikim.gov.my/index.php/en/artikel/7313-the-prospect-ofhalal-concept-for-muslim-manufacturers, accessed 14 March 2013.

Ismail, Zahari \& Abdul Halim Ehsan, 'Halal Nutraceutical Market: Issues and Challenges,' in Proceedings of the Asian Forum on Business Education 2008 on Contemporary Issues in doing Business in Asia, 3-4 December (Kuala Lumpur: University of Malaya, 2008).

Jaffar, Mariatul Aida \& Rosidah Musa, 'Determinants of Attitude towards Islamic Financing among Halal-Certified Micro and SMEs: APreliminary Investigation,' Procedia-Social and Behavioral Sciences, 130 (2014): 135-144.

Johnstone, Ronald L., Religion and Society in Interaction: The Sociology of Religion (New Jersey: Prentice Hall, 1975).

Mukhtar, Arshia \& Muhammad Mohsin Butt, 'Intention to Choose Halal Products: The Role of Religiosity,' Journal of Islamic Marketing, 3/2 (2012): 108-120.

Mustafa Afifi, A. H., Mahyeddin, M. M., Wati, M. K., Asming, Y., Najib, S. S. M., Asmidah, A., \& Ariff, M. M. I., 'Consumer Protection of Halal Products in Malaysia,' Middle-EastJournal of Scientific Research, 13 (2013): 22-28.

Mustafar, Mohd Zaid \& Joni Tamkin Borhan, 'Muslim Consumer Behavior: Emphasis on Ethics from Islamic Perspective,' Middle-East Journal of Scientific Research, 18/9 (2013): 1301-1307.

Oxford Business Group, 'The Report: Malaysia 2012,' https://books.google. com\, accessed 15 December 2015.

Phelps, D. M., 'Certification Marks Under the Lanham Act,' The Journal of Marketing (1949): 498-505.

Pnakj Rv Mo, 'Jakim Urged To Monitor Use ofHalal Logo at Hypermarkets,'The Edge, 19 August, 2013, BLIS, via IIUM Library, http://www.lib.iium. edu.my/index.jsp? module $=$ ROOT\&action $=$ onlinedb.jsp

Qaradawi, Y. Al., The Lawful and the Prohibited in Islam, $2^{\text {nd }}$ ed. (Cairo, Egypt: Al Falah Foundation for Translation, Publication \& Distribution, 2001).

Riaz, M. N. \& Chaudry, M. M., 'The Value of Halal Food Production-Mian N. Riaz and Muhammad M. Chaudry define what Halal and kosher foods are, describe why they are not the same thing, and what is required of processors and,' International News on Fats Oils and Related Materials (INFORM), 15/11 (2004): 698-701. 
Shatenstein, Bryna \& Parviz Ghadirian, 'Influences on Diet, Health Behaviours and their Outcome in Select Ethnocultural and Religious Groups,' Nutrition, 14/2 (1998): 223-230.

Suruhanjaya Syarikat Malaysia, 'Number of Registered Companies and Businesses,' https://www.ssm.com, accessed 2 December 2015.

Susanna Lim, 'Time to Expand Halal Exports Beyond the Current Horizon,' www.matrade.gov.my/.../2890-time-to-expand-halal-exports-beyondthe-current-hori., accessed 20 November 2016.

Zakaria, Zalina, 'Tapping into the World Halal Market: Some Discussions on Malaysian Laws and Standards,' Shariah Journal, 16/3 (2008): 603616.

\section{Statutes}

Administration of Muslim Act (AMLA).

Halal Certificate and Halal Label Order (2005).

Halal Meat Rules (2008).

Halal Product Guarantee Law (Act no. 33).

Trade Description Act (2011).

\section{Interview}

Othman Nawang (Deputy Director of Enforcement Division, Ministry of Domestic Trade, Cooperatives and Consumerism), in interview with author, 5 October 2015. 
Jurnal Syariah, Jil. 25, Bil. 1 (2017) 137-156 